\title{
Linking Expected Positive Performance Outcome, Professional Development and Performance Management: A PLS-SEM Approach
}

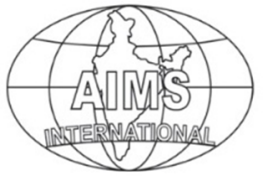

DOI: $10.26573 / 2018.12 .1 .4$

Volume 12, Number 1

January 2018, pp. 47-68

\author{
Sumi Jha \\ NITIE Mumbai \\ (sumijha05@gmail.com)
}

The purpose of the research was to study the relationship between expected positive performance outcome with performance management and professional development. The relationship has been studied from expectancy theory perspective. Mixed method was used to collect data. Quantitative data were collected using standard questionnaire and qualitative data were collected using the semi-structured interview. The sample size for quantitative study was 403 and for qualitative study was 15. The sample consisted of team leaders and team members of ICT organizations. Partial Least Square structural equation modeling (PLSSEM) was used to analyze the data. The paper aims to understand the relationship between expectations and performance. The paper also studied the mediating role of professional development. Significant relationships were found between independent and dependent variables. The paper explains the role of professional development in enhancing performance management system effectiveness. If employees' expectations of positive outcomes are matched with professional development, it will result in enhanced performance. It has been researched in an emerging market context.

Keywords: Expected Positive Performance Outcome, Professional, Mixed Method, Development, Performance Management, PLS-SEM

\section{Introduction}

Expected positive performance outcome is an important aspect of work performance, as recognized in academic (Tierney and Farmer, 2011) and practitioner-focused contexts (Amabile et al., 2002). The expected performance outcome is driven by the concept of innovation and creativity. Therefore, innovative behavior would influence creativity (Montag, Maertz \& Baer, 2012). The expectation of positive outcome drives employee creativity and organizational innovation and is positively related to individual and organizational effectiveness (Amabile, 1996). Employees' expectations direct organizations to focus on practices which will facilitate desired outcomes. The critical nature of effective human resource management practices has widely 
been acknowledged (Guest et al., 2003; Lips-Wiersma and Hall, 2007; Tessema and Soeters, 2006). Similarly, several studies have found that HRD practices affect the behavior and attitudes of employees (Edgar and Geare, 2005; Guest et al., 2003; Muse and Stamper, 2007; Pugh and Dietz, 2008). It is well-established fact that an organization is as good as its employees are. Employees are organization's crucial source of consistent competitive advantage (Pfeffer, 1996). Expectation to exceed performance level drives creative and innovative behavior among employees. It has widely been agreed that appropriate professional practices help employees in learning new concepts (Joo, 2010) and they try to implement newly learned practices to enhance performance (Schrock, et. al., 2016). Effective Performance management system makes each individual accountable for his/her own actions regardless of the results as the organization (superior) and individual (subordinate) mutually decide the definition of objectives, tasks, standards, and performance measures, monitoring progress and developing performance (Armstrong, 2000). The relationship between expected positive outcome, professional development, and performance management system has been built on the premise of expectancy theory of motivation (Dever, 2016; Ferris, 1977). Expectancy theory (Vroom, 1964; Pinder, 1984) states that behavioral choice (action) is dependent upon motivational force. This force is a function of the valence of expected outcomes and the expectancy that the action will be followed by anticipated outcomes. Whereas valence refers to the "affective orientation toward a particular outcome" (Vroom, 1964, p. 15), expectancy represents the "momentary belief concerning the likelihood that a particular act will be followed by a particular [desired] outcome" (Vroom, 1964, p. 17). Expectancy theory is based on the supposition that, when faced with behavioral alternatives, employees will choose the alternative that gives maximum positive and minimum negative return. While choosing the right program for professional development employees would expect a return from the program so that participants could perform creatively and effectively in their work and reinforce the positive outcome. Similarly, when organization practices performance management system employees mutually set goals and receive feedback on a continuous basis. This motivates employees to be creative, innovative and meet the expected positive outcome. Like decision theory, expectancy theory holds that "people choose (goals and talent management initiatives) in a way that maximizes expected utility" (Vroom, 1964, p. 19). The organization through professional development and performance management HR practices provides opportunities to employees to choose right talent management initiatives. It also helps employees receive continuous feedback on the job to choose the right path. In other words, expectancy theory is a process theory as "it attempts to identify relationships among variables in a dynamic state as they affect individual behavior" as well as a cognitive theory of motivation because "individuals are viewed as thinking, reasoning beings who have beliefs and anticipations concerning future events in their lives" (Steers and Porter, 1975, p. 180). Thus, the expectation of positive performance outcome would motivate employees to participate in professional development initiatives and performance management practices. Therefore, the paper attempts to understand the relationship between expected positive performance outcome, professional development initiatives and performance management practices. The relationship has been proposed from expectancy theory perspective. 
The format of the paper is as follows. The first section states the need for the study. In the second section, review of the literature, is presented. The third section summarizes the steps involved in research methodology. In the fourth section, the results and analysis of data are reported. These are then discussed considering expectancy theory. The final section presents conclusion, limitations and future scope of study.

\section{Need for the Study}

There are very few noted studies relating performance expectation and training initiatives taken by the organization. Training initiative for professional development influences career growth expectations among employees. Expectations enhance employees' willingness to learn (Joo, 2010). Employees may feel more attracted towards certain professional development programs because after attending those programs employees may fulfill the performance expectations. Expectations may improve their creativity and innovation level. There is a need to study whether expected positive performance outcome influences professional management initiatives in the organization? The rationale is based on expectancy theory which states that to achieve desired results individual would exert more effort (Dever, 2016; Ferris, 1977). The effort may be in terms of learning new skills and taking initiatives in talent management program. Employees' expectations would encourage organizations to start professional development initiatives and offer right learning opportunities for them. Employees' expectations from the organization may prepare the organization to respond to employees' requirements. Innovative employees would expect better professional development program and performance management system to ensure growth prospects in the organization.

Performance management system represents a central function of human resource management and has remained an important topic of investigation among organizational researchers (Dulebohn and Ferris, 1999). The relationship between expected positive performance outcome and performance management may be investigated, as the individual's desire to be innovative and creative would compel him/her to receive feedback, understand the importance of goal setting (Vancouver and Kendall, 2006; Vancouver and Schmitt, 1991) and understand the performance evaluation process. Expected positive performance outcome has been extensively studied with job performance and innovative outputs but its effect on people's perception regarding HR practices may be explored further (Guest et al., 2003; LipsWiersma and Hall, 2007; Tessema and Soeters, 2006).

\section{Literature Review}

This section summarizes the relevant literature for variables under study.

\subsection{Expected Positive Performance Outcome}

Expected positive performance outcomes are the expectations that innovative behavior will lead to performance or efficiency gains. Achieving performance gains is the uppermost reason employees would be creative and innovative in the workplace while performing a task (Yuan \& Woodmen, 2010). Innovative employees embrace the new idea to implement in the task. A new idea may bring in organizational change that might affect the organizational performance (Cingoz \& Akdogan, 2011). Workplace innovation has become one of the key drivers of long- 
term organizational growth and it has been considered that the outcomes are because of the creative and innovative individual behavior (Montag, Maertz \& Baer, 2012). Work of Fernandez and Moldogaziev (2012) stated that some employees apply innovative corrective measures to improve their performance, whereas, some employees do not promote innovation and face ineffective performance outcomes in the long run. After the pioneering study of Yuan and Woodmen (2010), between expected positive performance outcomes and individual innovative behavior, most innovation research followed efficiency-oriented perspective. Employees tend to innovate when they expect that doing so will bring efficiency gains for their work role and for their organizations. Organization adopts innovation to improve their efficiency (Abrahamson, 1991). The underlying assumption is that innovations serve the function of improving efficiency and that innovation decisions are based on expected positive performance outcomes (Yuan \& Woodmen, 2010).

Expectancies of success tend to enhance task performance. Employees tend to engage in an innovative behavior when they expect such behavior will improve the efficiency and performance of their work role or work unit. Though, enhanced individual job performance and efficiency may not always result in improved organizational outcomes as desired by an employee. Employees may feel more motivated and the expectations regarding positive outcomes will be stronger when an employee visualizes a strong relationship between effort and desired outcome.

Employees who observe innovativeness and creativity as part of their job/task requirement, have confidence that generating, adopting and implementing new ideas should benefit their work and improve performance (Yuan \& Woodmen, 2010). The concept of outcome expectancies is common across theories of behavioral science. Outcome expectancies are defined as "the person's estimate that a given behavior will lead to certain outcomes" (Bandura, 1977).

Several motivation and learning theories have noted the significance of outcome expectations in shaping an individual's behavior. Few attempts, though, have been made to directly conceptualize and test the effects of relevant outcome expectations for individual professional development needs and performance management practices.

\subsection{Professional Development}

The aim of effective professional development is to provide a platform where members are fully trained and competent to perform the tasks expected of them throughout their careers. A number of researchers have suggested that professional development may result in improved performance. For example, Eisenberger et al. (2001) believe that development opportunities provided by an organization oblige employees to behave reciprocally. McElroy (2001) opines that investment in employees creates a reputation for valuing and developing employees that attract and retains the best mind in the market. Horwitz, Heng, \& Quazi, (2003) found that professional development may impact competitive advantage not only through developing employees into a more competent workforce but also through affecting cost savings by being more innovative and creative and reducing things such as absenteeism and turnover rates (Kaye and Jordan-Evans, 2000; Lam and White, 1998). This may enhance the reputation of the organization through helping to recruit right employees for whom development experiences are generally attractive (Maurer, Weiss, \& Barbeite, 2003). Professional development has been studied with variables 
such as organizational learning culture and LMX quality (Joo, 2010) and professional development builds strong commitment among employees who see congruence between their own goals and those of the organization (Vancouver and Kendall, 2006; Vancouver and Schmitt, 1991). Employee development has a dual purpose of serving both the organization and employees in achieving mutual goals. It makes an employee realize that some way or the other organization takes care of him/her and about his/her progress toward personal or organizational goals. When the organization provides training to its employees, it helps them in their career development which they expect. Employees' sense of advancement and skills results into increased productivity for them and their team. They will have more fulfilling work and are less likely to leave the organization (Wong, Long, Ismail, \& Kowang, 2016).

Professional development is a collective and continuous effort of employee/employer with an interest to enrich employees' attitudes, knowledge, experiences, skills, and abilities and to improve their overall effectiveness and talent. A planned professional development is the one that integrates an individual's career needs and goals and the organization's requirements. If the planned development does not raise enough curiosity and positive performance expectations among employees it is challengeable (Talib, et al., 2013). The focus of professional development programs is to improve employee capabilities. When an organization invests in improving the knowledge and skills of its employees, the investment is returned in the form of more productive and effective employees. Researchers believe that employee reciprocates professional development initiatives of the organization. These initiatives act as indicators to the employees that the organization value their contributions and care about their career needs and manages potential talent (Wayne et al., 1997). Talent management through professional development programs is important as demographers assess that the composition of the future workforce would be quite diverse from the composition of the current workforce. Professional development would keep current employees updated and prepared for future requirements. At the same time, there remains a fear for the organization of losing substantial investment in terms of time and money in employee development because developed employees are more vulnerable to leave for a better job. Development in an employee's career is linked with a better future in a career. Organizations should realize that it is not only an employee's past performance but it is their potential and future personal development that makes the difference. Employees taking initiative for their own professional development is considered apt but if the initiative is in organizational context it works for both employer and employee. As employee/employer both get benefit from development programs, the organization should assist employees by providing them development opportunities (Haskell, 1993).

Researchers have identified continuous professional development as a critical element for employees (Maurer et al., 2003; Picchio and van ours, 2013). Both acquisitions of skill and knowledge and utilization of skill and knowledge are necessary for talent management. The organization which provides learning opportunities shall also provide application opportunities. Professional development practices provide the means for employees to update their existing skills and knowledge as well as to acquire new skills and knowledge. The acquisition of new skills may improve the expected performance outcome of employees. Such practices 
make employees more creative and innovative and have been found to increase the employability (Picchio and van ours, 2013). Colquitt and Simmering (1998) studied the link between goal orientation and two motivational constructs (i.e. expectancy and valence) in the training context. Their study found that learning orientation in which employees would learn for long-term impact was positively correlated with expectancy, valence, and motivation to learn. Performance orientation which was associated with short-term outcome was negatively correlated with expectancy and motivation to learn. Higher expectancy and valence levels were found for individuals who exhibited high learning-orientation. On the contrary, the findings of Smith et al. (2009) stated that both types of goal orientation (i.e. performance and learning) had significant positive paths to valence and expectancy.

\subsection{Performance Management}

According to Armstrong (2000), performance management is a means of getting better results from the whole organization or teams or individuals within it, by understanding and managing performance within an agreed framework of planned goals, standards and competence requirements. Researchers have suggested that organizational uncertainty, employer characteristic and the economic situation all impact performance measurement effectiveness, whilst Goold and Quinn (1990) argued that performance measurement effectiveness is contingent on the speed of change and the measurability of performance.

The applicability of performance management system as a managerial decision tool rests on its capability to provide accurate data on employee performance. According to Murphy and Cleveland (1991), frequently pursued goals of raters can be categorized into (1) task-performance goals (e.g. to motivate or maintain performance); (2) interpersonal goals (e.g. to maintain a positive work group climate); (3) strategic goals (e.g. to increase one's standing in the organization); and (4) internalized goals (e.g. to maintain one's values). Similarly, subordinates would like to get correct feedback on task and relationship related aspects and set goals for next year (Vancouver and Kendall, 2006; Vancouver and Schmitt, 1991). The correct rating would help employees being more experimenting in nature and engage in a creative and innovative task and experience positive expected performance outcomes.

Literature explained that organizations that have implemented performance management system perform better in both measurable and non-measurable aspects of the organizations in comparison to organizations that are less performance management driven (Quinn, 1990). This is explained by the fact that performance management clarifies goals, aligns organizational, departmental and individual goals in a strategically appropriate way. It also helps management to assess progress toward strategic goals (Langfield-Smith, 1997) and departments/employees to understand their role and contribution at a strategic level with greater clarity (Williams, \& O'Reilly III, 1998). Performance is typically judged subjectively because of non-measurable nature of some task (Ferris and Judge, 1991). Such subjectivity enables raters to bring bias in the process and talent management focus may shift from most potential candidate to less deserving candidate. This becomes a means to satisfy personal goals and to accommodate contextual demands (Fried and Tiegs, 1995). Despite the increase in experience gained with implementing this approach, there remain gaps between employees and management regarding 
understanding the purpose for which performance management has been implemented (Armstrong, 2000). Effective implementation of performance management shall influence employees' willingness to perform better and influence performance-driven behavior. For efficient and effective performance management, organizational members (managers and employees) need to display performancedriven behavior, which can be defined as increased performance expectation from self. The link between expected positive performance outcome and effectiveness of performance measures has been widely recognized but the explanations for this link are constrained by the lack of clear theoretical foundations (Holloway, 2001).

\section{Theoretical Framework and Hypothesis}

Vroom's expectancy theory defined valence as "affective orientations toward an outcomes" (p. 15). According to Vroom (1964, p. 15), "an outcome is positively valent when the person prefers attaining it to not attaining it' and 'an outcome has a valence of zero when the person is indifferent to attaining or not attaining it, and it is negatively valent when he prefers not attaining it to attaining it'. If employees will foresee any positive outcome or benefits by attending a professional development initiative, then the employees will attend the program with positive mindset otherwise not. According to Vroom (1964), expectancy can be defined as a transitory confidence followed by a completion of a task. Zero expectancy is an employees' subjective belief that the performance will not result in the desired outcome. On the other hand, expectancy of one is an employees' subjective belief that the performance will lead to the desired outcome. This estimation or belief is a function of expectations that individuals set based on his/her own capacities to influence outcomes (e.g. self-concept, self-efficacy, locus of control).

According to Burke and Baldwin (1999), there is numerous evidence suggesting that a considerable part of organizations' investment in professional development does not result in optimal transfer because of employees' belief regarding development program. Expected positive performance outcome among employees may result in a positive perception of professional development programs. Employees may perceive that the professional development program will help in developing innovative behavior. Willingness to innovate will encourage a willingness to learn through development programs. To be innovative and creative, the skills and behaviors learned and practiced during training shall be transferred to the workplace while performing a task (Holton and Baldwin, 2003). Skill transfer seems to be one of the most important outcomes of training, if it is associated with positive expectations. Expected positive performance outcome may influence performance development positively as the candidate having desire to innovate will learn the content of the training course sincerely (Noe, 1986; Noe and Schmitt, 1986). Further, candidate's perceptions that doing well in a program would lead to better job performance and consequently to valued outcomes (Mathieu et al., 1992).

H1: There will be significant positive relationship between expected positive performance outcome and Professional development

Organizational literature has long dealt with the concept of employees expected positive performance outcome and success of organizational processes (Malone, et. al., 1999). Performance management system as a process would be accepted by 
employees if they have positive expectancy towards the process. Expectancy also increases if employees associate supervisor and peer feedback as a source of a possible increase in levels of creativity and performance (Zhou, 2003; George and Zhou, 2007). From intrinsic motivation perspective (Ryan, Connell, \& Deci 1985), functional feedback enhances intrinsic motivation and thus the desire to perform a task well and excel (Zhou, 2003). The expectancy causes individuals to feel positive about the evaluation process of performance management, which partly has been shared in the form of feedback (Zhou, 2003). On the contrary, lack of expectation of feedback reduces the employees' willingness to perform better (Zhou, 2003; Zhou, \& Shalley, 2003). Bowen, \& Ostroff, (2004) advocated that employee's expectations from superior regarding fair and transparent performance management system would create a healthy feedback system.

H2: There will be significant positive relationship between expected positive performance outcome and performance management

Empirical evidence linking the availability of professional development opportunities and employee expected positive performance outcome is quite limited. Lee and Bruvold (2003) found that nurses who perceived they had more training and development opportunities were more satisfied with their jobs, more committed to their organization, and more likely to expect positive performance outcome. Shields and Ward (2001) found that satisfaction with training opportunities and promotion prospects had the strongest negative influence on nurses' intentions to quit. Acker (2004) found opportunities for professional development to be a significant positive predictor of willingness to design something innovative.

Employees with expected positive performance outcome would get encouraged to participate in professional development programs based on superior and peer feedback (Zhou, 2003; Zhou, \& Shalley, 2003). In this study, we also posit that professional development will mediate the effect of expected positive performance outcome such that the employees would be open to explore and engage in a potential identification and performance evaluation (Armstrong, 2000). Employees having positive orientation willing to apply innovative principles would appreciate organizations' effort towards professional development for talent management and skill development. Such employees would also see opportunities in performance management system for effective long-term performance (Armstrong, 2000; Montag, Maertz \& Baer, 2012). The expectations by supervisors compel subordinates to perform well and live up to the mark. The concept of Pygmalion effect summarizes similar findings (Collins, Hair, \& Rocco, 2009; Rosenthal, 1973). In sum, the expectation of innovative performance outcome should result in an increase in the willingness to take up professional development programs and have faith in performance management system of organization.

H3: There will be a significant positive relationship between professional development and performance management.

H4: Professional development will mediate the relationship between expected positive performance outcome and performance management. 


\section{Research Methods}

Mixed method research was conducted in two distinct phases: a quantitative phase (Phase I) and qualitative phase (Phase II). Results and findings obtained from phase-I were confirmed by implementing phase-II and finally, the finding and results derived from both the phases and methods have been analyzed. Mixed methods research has been accepted as one of the valuable research methods in social science studies (Creswell and Clark, 2011) as this research method provides a broad and in-depth analysis of phenomena under study and improves the validity of results and outcomes. According to Johnson and Onwuegbuzie (2004), mixed methods research is defined as "the class of research where the researcher mixes or combines quantitative and qualitative research techniques, methods, approaches, concepts or language into a single study". Tashakkori and Creswell (2007) defined mixed methods research as "research in which the investigator collects and analyses data, integrates the findings and draws inferences using both qualitative and quantitative approaches" (2007:3).

\subsection{Mixed Method Typologies}

Various mixed method typologies, developed by different researchers are presented in Table 1. Mertens (2007), Caracelli and Greene (1997), Creswell and Clark (2011) and Tashakkori and Teddlie (2003) distinguishes between mixed method design that uses both (Quan and Qual) methods to answer the research questions in a single study.

Table 1 Mixed Method Typologies

\begin{tabular}{|l|l|l|l|}
\hline Design Type & \multicolumn{1}{|c|}{ Timing } & \multicolumn{1}{|c|}{ Mix } & Weighting/Notation \\
\hline Triangulation & $\begin{array}{l}\text { Concurrent: quantitative } \\
\text { and qualitative at the } \\
\text { same time }\end{array}$ & $\begin{array}{l}\text { Merge the data during } \\
\text { interpretation or analysis }\end{array}$ & QUAN + QUAL \\
\hline Embedded & $\begin{array}{l}\text { Concurrent and } \\
\text { sequential }\end{array}$ & $\begin{array}{l}\text { Embed one type of data within } \\
\text { a larger design using the other } \\
\text { type of data }\end{array}$ & $\begin{array}{l}\text { QUAN (qual) or } \\
\text { QUAL (quan) }\end{array}$ \\
\hline Explanatory & $\begin{array}{l}\text { Sequential: Quantitative } \\
\text { followed by qualitative }\end{array}$ & $\begin{array}{l}\text { Connects the data between the } \\
\text { two phases }\end{array}$ & QUAN--- qual \\
\hline Exploratory & $\begin{array}{l}\text { Sequential: Qualitative } \\
\text { followed by quantitative }\end{array}$ & $\begin{array}{l}\text { Connects the data between the } \\
\text { two phases }\end{array}$ & QUAL--- quan \\
\hline \multicolumn{3}{|c|}{ Source: Adapted from Creswell \& Plano Clark (2007:85) } \\
\hline
\end{tabular}

The explanatory sequential design has been employed in two phases; which began with quantitative phase, followed by qualitative phase. By using the explanatory sequential design, the inferences were drawn about how the qualitative results helped to explain the quantitative results.

The rationale for using a mixed method research design is grounded in the fact that neither quantitative nor qualitative methods are sufficient, by themselves, to capture every detail of the study. In mixed method approach researchers use the combination of quantitative and qualitative methods to complement each other, which provides strong and assured analysis and inferences, because of the advantage of the strengths of each method (Greene, Caracelli, and Graham 1989; Miles and Huberman 1994; Greene and Caracelli 1997; Tashakkori and Teddlie 1998). 


\subsection{Phases of Explanatory Sequential Mixed Method Phase 1: Quantitative Research}

Study procedure: Data were collected from employees of ICT organizations. The choice of ICT organizations was based on the premise that they are generating maximum employment, hiring largest candidate pool and are facing the problem of attrition (NASSCOM, 2016). The stratified random sampling method was used to collect data from team leaders and members of project teams. A self-administered questionnaire-based survey was used to obtain the participants' views. After obtaining permission from HR heads of 7 ICT organizations of medium to large size, a total of 600 questionnaires were distributed among employees, resulting in 403 responses (response rate 67 percent). The sample comprised of $74 \%$ male respondents and $26 \%$ female respondents. The average age of respondents was 26 years. The average experience was 3 years. All the respondents were engineering graduates coming from the different stream. This was the first phase of the research design which was a cross-sectional survey; it involved the data collection and analysis with a self-administered standard questionnaire (Rubin, et. al., 2009).

\section{Phase 2: Qualitative Research (Semi-Structured Interviews)}

Study procedure: The second phase of the study was a qualitative study where semistructured interviews were conducted with 15 team leaders who were also the respondents of survey questions. There were 9 male respondents and 6 female respondents. The average age of team leaders were 27 years. The average experience of team leaders was 5 years. The open-ended questions were used to give an opportunity to the participants to express their opinions, knowledge, and feelings to provide rich contextual information, based on their experience (Cooper \& Schindler 2006; Creswell \& Clark 2011). The data from these interviews assisted in understanding how IT professionals understood and explored the problems of performance management system and professional development practices faced in the organization. Interviews were conducted in semi-structured (general interview guide approach) format (Goulding 2002; Patton 2002).

\section{Measures}

All measures used a response scale of 1-7 Likert scale, in which 1 was "strongly disagree" and 7 was "strongly agree."

Outcome Expectation: Expected positive performance outcomes were measured by three items modified (Yuan and Woodman, 2010) from House and Dessler's (1974) outcome expectancy scale. The maximum and minimum value ranged from 3 to 21 . The scale has items like "The more innovative I am, the better my job performance." The Cronbach's reliability value of the scale was $\alpha=0.77$.

Professional Development: Scale to measure professional development was conceptualized by Stumpf, Doh, and Tymon, Jr., (2010). It was measured by three items. The minimum and maximum value ranged from 3 to 21 . The scale has items like "Our organization's program for high potentials helps in talent retention." The Cronbach's reliability value of the scale was $\alpha=0.91$. 
Performance Management: Scale to measure performance management was developed by Stumpf, Doh, and Tymon, Jr., (2010). It denoted specific elements of the organization (i.e., goal setting, standards, evaluation, and feedback). It was measured by four items. The minimum and maximum value ranged from 4 to 28 . The scale has items like "The process of goal setting brings the best out of me." The Cronbach's reliability value of the scale was $\alpha=0.85$.

\section{Results and Analysis}

Data was analyzed using descriptive and inferential statistical tool. The mean value of expected performance outcome was 16.3, for professional development it was 12.7, and for performance management, it was 17.3. All the values were in the middle range of obtained minimum and maximum range. The correlation values showed significant positive relations between factors. The bivariate Pearson correlation depicted significant positive relationship $(\mathrm{r}=0.67, \mathrm{p}=0.01)$ between professional development and performance management. There is significant positive relationship $(\mathrm{r}=0.349, \mathrm{p}=0.01)$ between performance management and expected positive performance outcome. There is a significant positive correlation ( $\mathrm{r}$ $=0.394, \mathrm{p}=0.01$ ) between professional development and expected positive performance outcome.

To justify that the data is free from multicollinearity, tolerance test and Variance Inflation Factor test was conducted. Tolerance test value was 0.845 (acceptable limit above 0.2 ). Very small value (less than 0.2 ) indicates that the variable is redundant. The VIF value was 1.84 (acceptable limit below 5) (Cooper \& Schindler 200). To test the normality of data skewness and kurtosis test was conducted. The values of skewness for performance management, professional development, and expected positive performance outcome were $0.383,0.263,0.767$ respectively, which was well within range. The value of kurtosis for performance management, professional development, and expected positive performance outcome were $0.449,0.812,0.576$ respectively, which was also well within range (Cooper \& Schindler 2006).

Partial Least Squares (PLS) SEM was used to test the hypotheses generated. Smart PLS M2 Version 2.0 (Ringle et al., 2005) was used to analyze the data. Bootstrapping method (5000 resamples) was used to determine the significance levels for loadings, weights, and path coefficients (Chin, 1998; Gil-Garcia, 2008).

\subsection{Why PLS-SEM}

1. PLS- SEM is a causal modeling approach aimed at maximizing the explained variance of the dependent latent constructs. This is contrary to CB- SEM's objective of reproducing the theoretical covariance matrix, without focusing on explained variance.

2. When researchers' objective is prediction rather than confirmation of structural relationships then variance based PLS-SEM is preferred method. In another word, PLS-SEM is preferred method when the research objective is theory development and prediction.

3. PLS- SEM often provides more robust estimations of the structural model (Ringle et al. 2009). PLS-SEM is a regression- based approach that minimizes the residual variances of the endogenous construct. 
4. It is more robust with fewer identification issues, works with much smaller as well as much larger samples and can incorporate formative as well as reflective constructs.

5. It only permits recursive relationships in the structural model, therefore the structural paths between the latent constructs of the inner model can only head in the single direction. In the given model researcher is willing to study the relationship between professional development and performance management one way with the assumption that organizations would first train and then would measure the performance.

6. PLS-SEM can handle both formative and reflective measurement models. The present model is reflective model therefore, outer loadings are presented.

Measurement model: Two step approaches was used to test the measurement values as suggested by Anderson and Gerbing (1988). For reflective model, the internal consistency reliability should be higher than 0.70 (Gefen et al., 2000). The indicator loadings (outer loadings) values should be higher than 0.70 (Bagozzi and $\mathrm{Yi}, 1991)$. Convergent validity values, the average variance extracted, should be higher than 0.50 (Fornell and Larcker, 1981). As shown in Table 2 all values are well within range.

Table 2 Results of Measurement Model

\begin{tabular}{|c|c|c|c|c|c|}
\hline $\begin{array}{c}\text { Model } \\
\text { Constructs }\end{array}$ & $\begin{array}{c}\text { Outer } \\
\text { Loadings }\end{array}$ & $\begin{array}{c}\text { Average Variance } \\
\text { Extracted }\end{array}$ & $\begin{array}{l}\text { Composite } \\
\text { Reliability }\end{array}$ & R-square & $\begin{array}{c}\text { Cronbach's } \\
\text { Alpha }\end{array}$ \\
\hline eo1 & 0.885664 & & \multirow{4}{*}{0.89} & & \\
\hline eo2 & 0.925061 & & & & \\
\hline eo3 & 0.743290 & & & & \\
\hline EPOT & & 0.730 & & & 0.82 \\
\hline pd1 & 0.874578 & & \multirow{4}{*}{0.89} & & \\
\hline pd2 & 0.899747 & & & & \\
\hline pd3 & 0.808592 & & & & \\
\hline Prof Dev & & 0.742 & & 0.16 & 0.80 \\
\hline pm1 & 0.577209 & & \multirow{5}{*}{0.87} & & \\
\hline pm2 & 0.875067 & & & & \\
\hline pm3 & 0.870620 & & & & \\
\hline pm4 & 0.829904 & & & & \\
\hline Perf. Mgt & & 0.636 & & 0.47 & 0.82 \\
\hline
\end{tabular}

EPOT- Expected Positive Performance Outcome, Perf Mgt- Performance Management, Prof

Dev- Professional Development

The structural model was tested next. Indicator loadings were examined and bootstrapping was conducted to assess their significance. As per rule of thumb, the bootstrap sample was 5000 and the number of cases was 403 observations (sample). Critical t- value for all loadings were above 1.96 (significance level $=5$ percent). As all the indicator weights are significant, there is an empirical support to keep all the indicators. Structural model rules suggest that the $\mathrm{R}^{2}$ values of $0.75,0.50$ or 0.25 for 
endogenous latent variables in the structural model can be described as substantial, moderate or weak respectively. In the present study, the $\mathrm{R}^{2}$ value for a dependent variable in the model was 0.474 , which may be considered as moderate (Table 2).

The bootstrapping with same sample specifications resulted in significant relationships with values above 1.96 (Significance level $=5$ percent). Predictive relevance was calculated using blindfolding to obtain cross-validated redundancy measures for each construct. The default omission distance chosen was 7 . The $\mathrm{Q}^{2}$ values larger than zero indicate that the exogenous constructs have predictive relevance.

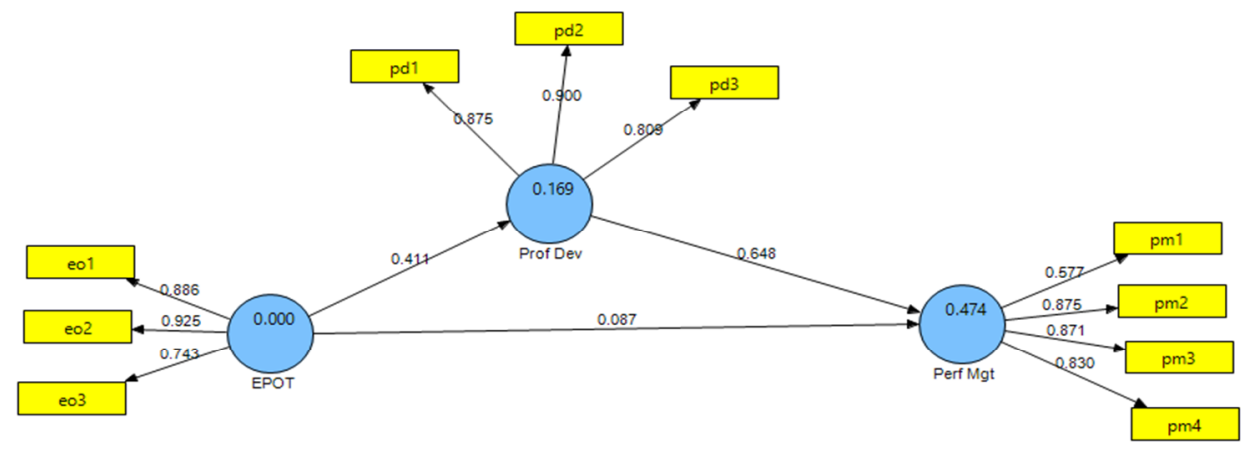

Figure 1 Model Depicting Antecedents of Performance Management

Results are presented in Table 3 and Figure 1. The regression coefficient values for direct effects between professional development and performance management (0.65) and between expected positive performance outcome and performance development $(0.411)$ were higher than the coefficient value of direct effect between expected positive performance outcome and performance management (0.08). All tvalues are above 0.196 indicating significant relationships. As shown in Table 3, though, all hypotheses were fully supported, the relationship between expected positive performance outcome and performance management is weaker than other relations. This indicates partial mediation.

Table 3 Path Coefficients and Hypothesis Testing

\begin{tabular}{|l|c|c|c|}
\hline & $\begin{array}{c}\text { Regression } \\
\text { coefficients }\end{array}$ & t- value & $\begin{array}{c}\text { Hypothesis } \\
\text { support }\end{array}$ \\
\hline EPOT $\longrightarrow$ Perf Mgt & 0.08 & 2.08 & Support \\
\hline Prof. Dev $\longrightarrow$ Perf Mgt & 0.65 & 17.939 & Support \\
\hline EPOT $\longrightarrow$ Prof Dev & 0.411 & 9.341 & Support \\
\hline EPOT $\longrightarrow$ Prof. Dev $\longrightarrow$ Perf Mgt & 0.57 & 13.28 & Support \\
\hline
\end{tabular}

EPOT-Expected Positive Performance Outcome, Perf Mgt- Performance Management, Prof Dev-Professional Development

\section{Discussion}

In the context of expectancy theory, Hypothesis 1 stating expected positive performance outcome and professional development practices will have a significant 
positive relationship $(\beta=0.411, p=0.01)$ has been accepted. Positive expectancy results in employees experiencing positive work-related attitudes, such as satisfaction, with activities they are engaged in (Gould-Williams, 2007). Our findings in congruence with researchers (Guest et al., 2003; Lips-Wiersma and Hall, 2007; Tessema and Soeters, 2006) indicate that employees having expected positive performance outcome perceives initiatives of HR practices positively and consider professional development opportunities will enhance the innovation capabilities which in turn may help in performance enhancement. Some of the team leaders opined that positive expectancy regarding development initiatives, on "how to provide feedback" would help team leaders encourage giving and receiving feedback for innovation driven behavior.

"Team members should give regular, real-time feedback to their subordinates on innovation initiatives. It could be informally over chat or a formal session."

"Some of my team members know which career path is right for long-term growth."

"Team leaders may be provided a professional development session on how to motivate employees for innovative behavior."

"Employees think receiving right professional development opportunities enhances their capabilities. Some of us take initiative to implement what we learned in our professional development courses.

One of the dimensions of expected positive performance outcome states that 'Coming up with creative ideas helps me do well on my job'. It would be ideal if the creative ideas generated by employees will be tamed through professional development practices. The nurtured creative idea then would result in enhanced performance. This phenomenon may also be stated as higher the willingness to have clarity of team objectives, bring in creative ideas and be innovative, more the employees would like to nurture their own as well as their subordinates' talent via professional development practices (Dever, 2016; Ferris, 1977; Eisenberger et al. 2001). In congruence with expectancy theory, the valence and expectancy increase if the quality of professional development plan is considered good in the past by members who have been part of it.

Hypothesis 2 regarding a significant positive relationship between expected positive performance outcome and performance management $(\beta=0.08, p=0.05)$ was supported but the coefficient value was low. Echoing Pygmalion effect (Collins, Hair, \& Rocco, 2009; Rosenthal, 1973), performance management refers to the ability of team leaders and team members to understand the process of directing and supporting employees to work as effectively and efficiently as possible in line with the needs of the organization (Schaubroeck, et al., 2016). Employees understand the importance of performance management because it is a continuous process which starts with goal setting, moves to providing feedback and then evaluation of performance (Armstrong 2000). Employees' perception of being innovative is possible if the set goals would allow such activities. Not every goal would require continuous innovation. Team leader's opinion also matched with the findings which stated,

"Though being innovative is important but it is bounded by task we perform." 
"Expecting good performance to a great extent is dependent on the vibes (feedback) we receive from our superior."

Employees like to innovate, they have an innate desire to experiment by creating new technologies and new ways of doing things, and people want to do competent work, a job well done allows them to exercise their skills and receive satisfaction from their competence (Kim, Eisenberger, \& Baik, 2016). One of the employees remarked

"I want to grow and to grow in an organization.... [like this]....one has to think out of the box and provide quick response to clients."

Therefore, the relationship between employees expected performance outcome and performance management system stands ground.

Hypothesis 3 which predicted the relationship between professional development and performance management was supported with significant $(\beta=0.65, p=0.01)$ values of coefficients and was justified with the help of interview responses. Professional development practices will improve the ability to set goals, conduct a proper evaluation and give and receive feedback effectively (Zhou, 2003; Zhou, \& Shalley, 2003). The goal setting training, for example, would prepare employees for goal setting exercise. This exercise will have an immediate bearing on the goals set by team leaders for the next financial year.

"Clarity regarding management expectations and task to be achieved by team members reduces the anxiety "

"Training on goal setting exercise helped me tremendously. I started involving all my team members to set project goals."

Professional development is also a process of identifying potential employees. The gap in competency to get promoted may be filled by well-developed professional development program (Dever, 2016; Ferris, 1977; Armstrong, 2000). Superiors would provide timely feedback to such candidate and prepare them for the next role as a performance management process. Team members are active agents who determine the extents to which a given professional development programs are valuable for them to reach to the next level. Employees specifically identified practice-based experiences as being preferred ways of developing their knowledge and skills (Armstrong-Stassen and Schlosser 2008).

Hypothesis 4 which states professional development will mediate the relationship between expected positive performance outcome and performance management, was accepted. The indirect relationship between expected positive performance outcome and performance management via professional development was stronger $(\beta=0.57$, $\mathrm{p}=0.01)$ than the direct effect between expected positive performance outcome and performance management $(\beta=0.08, \mathrm{p}=0.05$ ) According to Johnston, \& Marshall, (2016), organizations contribute in important ways to the desire of employees to engage in career development activities as a part of performance management initiative. They specifically noted that opportunities for training and challenging work contribute to career development behavior (Lips-Wiersma, \& Hall, 2007). Respondents perceived a lack of availability of training and development 
opportunities and less involvement in the mentoring process are targeted to nonperformers.

"Creativity and innovation require discussion with like-minded employees. It also requires support and mentoring from superiors"

Being innovative in ways to complete tasks before time brings appreciation from the client side. It gets noticed in the organization.

"Being positive+ being at right place+ being able to grab challenging tasks are key elements of success."

According to Tessema and Soeters, (2006) employees with positive expectancy dwell into looking for alternative ways of doing a task to get better results. This may require skill enhancement through professional development practices. Employees perform with the expectation that better output of task would result in monetary or non-monetary benefits to the team (Hoch, \& Dewa, 2016). The team leaders must evaluate objectives, prioritize them and involve team members in discussion and come up with priorities. Challenges make employees stretch their capabilities. Employees may need to undergo professional development program to meet challenges and improve expected output. The valance that employees set on the effectiveness of training and the usefulness of challenge motivates them to exceed performance (Colquitt, \& Simmering, 1998).

\section{Conclusion, Managerial Implications and Future Scope of Study}

The paper was aimed to explore the relationship between expected positive performance outcome, professional development and performance management from expectancy theory perspective. Significant relationships between variables were found. The study also indicated the presence of partial mediation effect of the variable professional development while studying the relationship between expected positive performance outcome and performance management.

Managerial implications of the results are considerable as managers shall try to create positive expectancy among employees for innovative behavior and believe in the fact that creativity and innovation will improve employees and organizational performance. Because of positive expectancy regarding performance outcome employees would sincerely take part in the performance management and professional development practices. The belief in these practices will help in developing HR practices as per the employees and organizational current and future requirement. The model will help managers in changing past HR practices, as employees' orientation is moving toward innovation. Policies to improve innovation would get instituted in the organization because of a direct relationship of these with improved performance. Further, managers must understand the importance of open feedback provided to subordinates. The feedback set expectations in the mind of subordinates. A training session on how to provide feedback and set expectations would be valuable for the organizations. Another important aspect that the managers should focus on is relevance of training programme or professional development programme provided to employees. Non relevant training programmes may not motivate employees to perform. 
The cross-sectional investigation generates limitations as the performance management and professional development practices are a continuous long-term process (Weerakkody et al., 2016). A longitudinal study in this regard would be advisable. A study investigating different personality type experiencing different expectancy would help HR practitioner in developing customized training and development programs. The comparative study between work profiles which requires continuous innovation and profiles which do not require continuous innovation would help in understanding the role of job characteristics in studying the stated relationships.

\section{References}

1. Abrahamson, E. (1991). Managerial fads and fashions: The diffusion and rejection of innovations. Academy of management review, 16(3), 586-612.

2. Acker, G. M. (2004). The effect of organizational conditions (role conflict, role ambiguity, opportunities for professional development, and social support) on job satisfaction and intention to leave among social workers in mental health care. Community Mental Health Journal, 40(1), 65-73

3. Amabile, T. M., Hadley, C. N., \& Kramer, S. J. (2002). Creativity under the gun. Harvard business review, 80, 52-63.

4. Amabile, T. M. (1996). Creativity in context: Update to" the social psychology of creativity.". Westview press.

5. Anderson, J. C., \& Gerbing, D. W. (1988). Structural equation modeling in practice: A review and recommended two-step approach. Psychological bulletin, 103(3), 411.

6. Armstrong, S. J. (2000). The influence of individual cognitive style on performance in management education. Educational Psychology, 20(3), 323339.

7. Armstrong-Stassen, M., \& Schlosser, F. (2008). Benefits of a supportive development climate for older workers. Journal of managerial psychology, 23(4), 419-437.

8. Bagozzi, R. P., \& Yi, Y. (1991). Multitrait - multimethod matrices in consumer research. Journal of Consumer Research, 17(4), 426-439.

9. Bandura, A. (1977). Self-efficacy: toward a unifying theory of behavioral change. Psychological review, 84(2), 191.

10. Bowen, D. E., \& Ostroff, C. (2004). Understanding HRM-firm performance linkages: The role of the "strength" of the HRM system. Academy of management review, 29(2), 203-221.

11. Burke, L. A., \& Baldwin, T. T. (1999). Workforce training transfer: A study of the effect of relapse prevention training and transfer climate. Human resource management, 38(3), 227-241.

12. Caracelli, V. J., \& Greene, J. C. (1997). Crafting mixed-method evaluation designs. New directions for evaluation, 1997(74), 19-32.

13. Chin, W. W. (1998). The partial least squares approach to structural equation modeling. Modern methods for business research, 295(2), 295-336. 
14. Cingöz, A., \& Akdoğan, A. A. (2011). An empirical examination of performance and image outcome expectation as determinants of innovative behavior in the workplace. Procedia-Social and Behavioral Sciences, 24, 847853.

15. Collins, M. H., Hair Jr, J. F., \& Rocco, T. S. (2009). The older-worker-younger-supervisor dyad: A test of the Reverse Pygmalion effect. Human resource development quarterly, 20(1), 21-41.

16. Colquitt, J. A., \& Simmering, M. J. (1998). Conscientiousness, goal orientation, and motivation to learn during the learning process: A longitudinal study. Journal of applied psychology, 83(4), 654.

17. Cooper, D. R., \& Schindler, P. S. (2006). Marketing research. New York: McGraw-Hill/Irwin

18. Clark, V. P., \& Creswell, J. W. (2011). Designing and conducting mixed methods research. Retrieved on July, 25, 2014.

19. Dulebohn, J. H., \& Ferris, G. R. (1999). The role of influence tactics in perceptions of performance evaluations' fairness. Academy of Management journal, 42(3), 288-303.

20. Dever, B. V. (2016). Using the Expectancy-Value Theory of Motivation to Predict Behavioral and Emotional Risk among High. School Psychology Review, 45(4), and 417.

21. Edgar, F., \& Geare, A. (2005). HRM practice and employee attitudes: different measures-different results. Personnel review, 34(5), 534-549.

22. Eisenberger, R., Armeli, S., Rexwinkel, B., Lynch, P. D., \& Rhoades, L. (2001). Reciprocation of perceived organizational support. Journal of applied psychology, 86(1), 42.

23. Fernandez, S., \& Moldogaziev, T. (2012). Using employee empowerment to encourage innovative behavior in the public sector. Journal of Public Administration Research and Theory, mus008.

24. Ferris, G. R., \& Judge, T. A. (1991). Personnel/human resources management: A political influence perspective. Journal of management, 17(2), 447-488.

25. Ferris, K. R. (1977). A test of the expectancy theory of motivation in an accounting environment. Accounting review, 605-615.

26. Fornell, C., \& Larcker, D. F. (1981). Structural equation models with unobservable variables and measurement error: Algebra and statistics. Journal of marketing research, 382-388.

27. Fried, Y., \& Tiegs, R. B. (1995). Supervisors' role conflict and role ambiguity differential relations with performance ratings of subordinates and the moderating effect of screening ability. Journal of applied psychology, 80(2), 282.

28. Gefen, D., Straub, D., \& Boudreau, M. C. (2000). Structural equation modeling and regression: Guidelines for research practice. Communications of the association for information systems, 4(1), 7.

29. George, J. M., \& Zhou, J. (2007). Dual tuning in a supportive context: Joint contributions of positive mood, negative mood, and supervisory behaviors to employee creativity. Academy of Management Journal, 50(3), 605-622.

30. Gil-Garcia, J. R. (2008). Using partial least squares in digital government research. Handbook of research on public information technology. Idea Group, Hershey, 239-253. 
31. Goold, M., \& Quinn, J. J. (1990). The paradox of strategic controls. Strategic Management Journal, 11(1), 43-57.

32. Goulding, C. (2002). Grounded theory: A practical guide for management, business and market researchers. Sage.

33. Gould-Williams, J. (2007). HR practices, organizational climate and employee outcomes: evaluating social exchange relationships in local government. The International Journal of Human Resource Management, 18(9), 1627-1647.

34. Greene, J. C., \& Caracelli, V. J. (1997). Defining and describing the paradigm issue in mixed-method evaluation. New directions for evaluation, 1997(74), 5 17.

35. Greene, J. C., Caracelli, V. J., \& Graham, W. F. (1989). Toward a conceptual framework for mixed-method evaluation designs. Educational evaluation and policy analysis, 11(3), 255-274.

36. Guest, D. E., Michie, J., Conway, N., \& Sheehan, M. (2003). Human resource management and corporate performance in the UK. British journal of industrial relations, 41(2), 291-314.

37. Haskell, F. (1993). History and its Images: Art and the Interpretation of the Past. Yale University Press.

38. Hoch, J. S., \& Dewa, C. S. (2016). Walk Long and Prosper: What Is the Optimal Way to Help People Achieve Their Goals? Journal of general internal medicine, $1-2$.

39. Holloway, J. (2001). Investigating the impact of performance measurement. International Journal of Business Performance Management, 3(2-4), 167-180.

40. Holton III, E. F., \& Baldwin, T. T. (2003). Improving learning transfer in organizations. John Wiley \& Sons.

41. House, R. J., \& Dessler, G. (1974). The path-goal theory of leadership: Some post hoc and a priori tests. Contingency approaches to leadership, 29, 55.

42. Johnson, R. B., \& Onwuegbuzie, A. J. (2004). Mixed methods research: A research paradigm whose time has come. Educational researcher, 33(7), 14-26.

43. Johnston, M. W., \& Marshall, G. W. (2016). Sales force management: Leadership, innovation, technology. Routledge.

44. Joo, B. K. B. (2010). Organizational commitment for knowledge workers: The roles of perceived organizational learning culture, leader-member exchange quality, and turnover intention. Human resource development quarterly, 21(1), 69-85.

45. Kaye, B., \& Jordan-Evans, S. (2000). Retention: tag, you're it!. Training and Development-Alexandria-American Society for Training and Development, 54(4), 29-39.

46. Kim, K. Y., Eisenberger, R., \& Baik, K. (2016). Perceived organizational support and affective organizational commitment: Moderating influence of perceived organizational competence. Journal of Organizational Behavior.

47. Lam, L. W., \& White, L. P. (1998). Human resource orientation and corporate performance. Human Resource Development Quarterly, 9(4), 351-364.

48. Langfield-Smith, K. (1997). Management control systems and strategy: a critical review. Accounting, organizations and society, 22(2), 207-232.

49. Langfield-Smith, K. (1997). Management control systems and strategy: a critical review. Accounting, organizations and society, 22(2), 207-232. 
50. Lips-Wiersma, M., \& Hall, D. T. (2007). Organizational career development is not dead: A case study on managing the new career during organizational change. Journal of Organizational Behavior, 28(6), 771-792.

51. Mathieu, J. E., Tannenbaum, S. I., \& Salas, E. (1992). Influences of individual and situational characteristics on measures of training effectiveness. Academy of management journal, 35(4), 828-847.

52. Maurer, T. J., Weiss, E. M., \& Barbeite, F. G. (2003). A model of involvement in work-related learning and development activity: the effects of individual, situational, motivational, and age variables. Journal of applied psychology, 88(4), 707.

53. Horwitz, F. M., Heng, C. T., \& Quazi, H. A. (2003). Finders, keepers? Attracting, motivating and retaining knowledge workers. Human resource management journal, 13(4), 23-44.

54. Malone, T. W., Crowston, K., Lee, J., Pentland, B., Dellarocas, C., Wyner, G., ... \& Klein, M. (1999). Tools for inventing organizations: Toward a handbook of organizational processes. Management Science, 45(3), 425-443.

55. McElroy, J. C. (2001). Managing workplace commitment by putting people first. Human Resource Management Review, 11(3), 327-335.

56. Mertens, D. M. (2007). Transformative paradigm mixed methods and social justice. Journal of mixed methods research, 1(3), 212-225.

57. Miles, M. B., \& Huberman, A. M. (1994). Qualitative data analysis: An expanded sourcebook. Sage.

58. Montag, T., Maertz, C. P., \& Baer, M. (2012). A critical analysis of the workplace creativity criterion space. Journal of Management, 38(4), 1362-1386.

59. Murphy, K. R., \& Cleveland, J. N. (1991). Performance appraisal: An organizational perspective. Allyn \& Bacon.

60. Muse, L. A., \& Stamper, C. L. (2007). Perceived organizational support: Evidence for a mediated association with work performance. Journal of Managerial Issues, 517-535.

61. NASSCOM, (2016), HR Trends Shaping India's IT-BPO Landscape http://www.nasscom.in/hr-trends-shaping-india\%e2\%80\%99s-itbpolandscape?fg=71029 Accessed on 9/1/17\}

62. Noe, R. A., \& Schmitt, N. (1986). The influence of trainee attitudes on training effectiveness: Test of a model. Personnel psychology, 39(3), 497-523.

63. Noe, R. A. (1986). Trainees' attributes and attitudes: Neglected influences on training effectiveness. Academy of management review, 11(4), 736-749.

64. Patton, M. Q. (2002). Two decades of developments in qualitative inquiry a personal, experiential perspective. Qualitative social work, 1(3), 261-283.

65. Pfeffer, J. (1996). When it comes to "best practices"-Why do smart organizations occasionally do dumb things?. Organizational Dynamics, 25(1), 33-44.

66. Picchio, M., \& van Ours, J. C. (2013). Retaining through training even for older workers. Economics of Education Review, 32, 29-48.

67. Pugh, S. D., \& Dietz, J. (2008). Employee engagement at the organizational level of analysis. Industrial and Organizational Psychology, 1(01), 44-47. 
68. Talib, F., Rahman, Z., \& Qureshi, M. N. (2013). An empirical investigation of relationship between total quality management practices and quality performance in Indian service companies. International Journal of Quality \& Reliability Management, 30(3), 280-318.

69. Ryan, R. M., Connell, J. P., \& Deci, E. L. (1985). A motivational analysis of self-determination and self-regulation in education. Research on motivation in education: The classroom milieu, 2, 13-51.

70. Ringle, C. M., Wende, S., \& Will, A. (2005). SmartPLS 2.0 (beta).

71. Rosenthal, R. (1973). The Pygmalion Effect Lives. Psychology today.

72. Rubin, R. B., Rubin, A. M., \& Haridakis, P. M. (2009). Communication research: Strategies and sources. Cengage Learning.

73. Shields, M. A., \& Ward, M. (2001). Improving nurse retention in the National Health Service in England: the impact of job satisfaction on intentions to quit. Journal of health economics, 20(5), 677-701.

74. Smith, R. E., Smoll, F. L., \& Cumming, S. P. (2009). Motivational climate and changes in young athletes' achievement goal orientations. Motivation and Emotion, 33(2), 173-183.

75. Steers, R. M \& Porter. L. W, (1975), Motivation and work behavior, McGrawHill,

76. Stumpf, S. A., Doh, J. P., \& Tymon, W. G. (2010). The strength of HR practices in India and their effects on employee career success, performance, and potential. Human Resource Management, 49(3), 353-375.

77. Schrock, W. A., Hughes, D. E., Fu, F. Q., Richards, K. A., \& Jones, E. (2016). Better together: Trait competitiveness and competitive psychological climate as antecedents of salesperson organizational commitment and sales performance. Marketing Letters, 27(2), 351-360.

78. Schaubroeck, J., Carmeli, A., Bhatia, S., \& Paz, E. (2016). Enabling team learning when members are prone to contentious communication: The role of team leader coaching. Human Relations, 0018726715622673.

79. Tashakkori, A., \& Creswell, J. W. (2007). Editorial: The new era of mixed methods. Journal of mixed methods research, 1(1), 3-7.

80. Tashakkori, A., \& Teddlie, C. (2003). Handbook of mixed methods in the social and behavioral sciences.

81. Tashakkori, A., \& Teddlie, C. (1998). Mixed methodology: Combining qualitative and quantitative approaches (Vol. 46). Sage.

82. Teddlie, C., \& Tashakkori, A. (Eds.). (2009). Foundations of mixed methods research: Integrating quantitative and qualitative approaches in the social and behavioral sciences. Sage Publications Inc.

83. Tessema, M. T., \& Soeters, J. L. (2006). Practices and challenges of converting former fighters into civil servants: the case of Eritrea. Public administration and development, 26(4), 359-371.

84. Tierney, P., \& Farmer, S. M. (2011). Creative self-efficacy development and creative performance over time. Journal of Applied Psychology, 96(2), 277.

85. Vancouver, J. B., \& Kendall, L. N. (2006). When self-efficacy negatively relates to motivation and performance in a learning context. Journal of Applied Psychology, 91(5), 1146. 
86. Vancouver, J. B., \& Schmitt, N. W. (1991). An exploratory examination of person-organization fit: Organizational goal congruence. Personnel psychology, 44(2), 333-352.

87. Wayne, S. J., Shore, L. M., Bommer, W. H., \& Tetrick, L. E. (2002). The role of fair treatment and rewards in perceptions of organizational support and leadermember exchange. Journal of applied psychology, 87(3), 590.

88. Weerakkody, V., Osmani, M., Waller, P., Hindi, N., \& Al-Esmail, R. (2016). Situating Continuing Professional Development in Life Long Learning in Qatar. International Journal of Business and Management, 11(11), 81.

89. Williams, K. Y., \& O'Reilly III, C. A. (1998). A review of 40 years of research. Res Organ Behav, 20, 77-140.

90. Wong, M., Long, C. S., Ismail, W. K. W., \& Kowang, T. O. (2016). The Influence of Employee Perceptions of Training on Turnover Intention. International Information Institute (Tokyo). Information, 19(8A), 3197.

91. Yuan, F., \& Woodman, R. W. (2010). Innovative behavior in the workplace: The role of performance and image outcome expectations. Academy of Management Journal, 53(2), 323-342.

92. Zhou, J. (2003). When the presence of creative co-workers is related to creativity: role of supervisor close monitoring, developmental feedback, and creative personality. Journal of applied psychology, 88(3), 413.

93. Zhou, J., \& Shalley, C. E. (2003). Research on employee creativity: A critical review and directions for future research. Research in personnel and human resources management, 22, 165-218.

\section{About Our Author}

Sumi Jha is a faculty of Organisational Behaviour and Human Resource Management at National Institute of Industrial Engineering (NITIE), Mumbai, India. She has done her Fellow Programme in Management (FPM) in the area of Employee Empowerment form National Institute of Industrial Engineering (NITIE). Her research interests are in strategic leadership, employee empowerment, competency management, and organisational health. She has published research papers in national and international journals of repute. She also has primary teaching cases to her credit. She has been awarded Emerald Literati Awards for Excellence: Highly Commended Paper Award - 2014 and Emerald Outstanding Reviewer Award-2017. 